\title{
Language Issues: Variation of Gender Discourse on University Campus
}

\author{
Dr. Dorjana Klosi
}

English language Department, Faculty of Human Sciences, University of "Ismail Qemali" dorianaklosi@gmail.com

Doc. Lulzim Hajnaj

Department of Education, Faculty of Human Sciences, University of "Ismail Qemali" lulzimhajnaj@yahoo.com

Doi:10.5901/ajis.2015.v4n3s1p312

\section{Abstract}

Does gender affect language use? Well, during all these years there have been a number of studies on language and gender, conducted by both men and women. Conclusions of some of these studies are somewhat similar, but other studies claim their contraversional findings. There are a number of studies, which could not escape the inherited mentality of masculine and feminism. Our study is an exchange of past and present linguistic data and research. Legends on language and gender, cultural stereotypes, the latest linguistic theories on language based on gender, questionnaire and two case studies are the main elements of our research. We try to answer to questions: do male and female use language for the same or different purpose? At what extend do the social and cultural contexts affect thinking and as a consequence the language itself?

Keywords: gender variable, stereotypes, cultural and social mentality.

\section{Objectives}

- How language reveals, embodies and supports gender attitudes.

- How language users speak in different and special ways that reflect their gender.

- $\quad$ Can cultural and social conditionality affect gender attitudes in speaking and writing?

- $\quad$ Are there objective differences between the language of men and women?

- Can any social factor completely eliminate these differences?

\section{Theoretical Framework}

The latest theoretical perspectives on this topic are mentioned to reflect more accurately the relationship between language and gender. Previous theories (Johnson 1997:68) of use of language were based on gender dichotomy: men and women were at odds with each other. But this theory leaves aside the fact that both sexes use the same linguistic resources and use line communication system. However, it's important not to forget that linguistic differences between the sexes are not encouraged by linguistic elements, but these changes are the product of social processes and practices. Being a boy or girl is "made up" by society ${ }^{1}$ (Ferguson, N, 1977, 153-162)-a process in which language plays a key role.

\section{Legends on Language and Gender}

Linguistic diversity coexists with social diversity. There is not any case, in which social community and ethno-cultural community are linguistically and /or socially homogeneous. Basing on recent discussion on language and gender, five factors affect linguistic behavior: age, gender, ethnicity, social and economic class and education ${ }^{2}$. The three first factors

\footnotetext{
1 Johnson, S., \& Meinhof, U. H., Language and masculinity, Oxford, 1999, f. 310.

2 Bodine, A., Review of: Male/Female Language, Cambridge , 1977 , f. 104-110
} 
are quite natural but the two last factors are socially based.

Linguists, such as Johnson and Meinhof ${ }^{3}$ claim that hypothesis on gender discourse are based on the dichotomy gender-society. Under the social view, males and females are on "conflicting" relations.

A quick look at linguistic models on language and gender and Albanian social realities brings into light an indisputable fact: most of our linguistic behavior is based on stereotypes. Such social stereotypes are taught and learned to us since childhood 4 .

K. Basin (2006:23) claims that all gender differences reflected in language are product of society. Language itself is overloaded with stereotypes, proverbs, anecdotes and sayings about females. Probably, the most known stereotype is that girls and women talk a lot.... A look on the history of gender issues can result in the fact that certain important people have expressed their opinion in relation to women position in society ${ }^{5}$.

Few examples:

Aristotle "the courage of a man is when he commands, the courage of a woman when she obeys".

Sigmund Freud "women's anatomy is their destiny. Females are a deviant of human being."

Charles Darwin "intuition or perception are more obvious in women than men. But such abilities are characteristics of an inferior race and as a result, belonging to a passed or earlier stage of evolution. "

On the other side, Albanian language might be considered as a patriarchal language. Throughout the years, Albanian sociolinguists have brought examples of our culture about gendered language ${ }^{6}$. Such stereotypes picture girls and women as talkative and men are assertive in their declaration. But these cultural, generic statements about gender language are not proved scientifically.

Every society determines certain rules about males and females' position and duties in and out home. These norms influence all the aspects of their lives as a consequence they are reflected in linguistic behavior of both genders. The way males and females talk; define the "individual" usage of language. Gordon 7and Eman ${ }^{8}$ claim that social features of the gendered language influence greatly individual behavior.

\section{Results}

Our study aims to

- prove that these claims are true;

- find out if language gender division is a reality among students at University of "Ismail Qemali", Vlore;

- how it affects gender communication.

The first objective is to find out if there are differences between male and female communication. Firstly, we thought that the major difference on both gender communications would be in the term of politeness. Our assumption is justified because terms of politeness show how individuals relate to the outside world 9 . To explain it better, we examined a large number of words which describe psychological conditions and social process, including friends, family, emotions etc.

The second objective is focused in determining the role of social and cultural contexts in gender communication. Albanian linguistic studies on this aspect are just a few. They are mostly theoretical and lack practical part.

However, there is a question rising about gender communication: which gender is more effective in communication? The answer is found in linguistic data gathered from students of University of "Ismail Qemali", Vlore. We found that there are linguistic differences among boys and girls, but such changes are not essential.

\footnotetext{
${ }^{4}$ Manual për të rinjtë e mësuesit: Adoleshentët dhe çështjet gjinore: perspektiva gjinore. Tiranë, 2005, f. 8.

${ }^{5}$ Bhasin, K., Të kuptosh përkatësinë gjinore, Tiranë, 2006, f. 23.

${ }^{6}$ Manual për të rinjtë dhe mësuesit: Adoleshentët dhe çështjet gjinore, Tiranë, 2005, f. 5.

7 Gordon, E., Sex, Speech, and Stereotypes: Why Women Use Prestige Speech Forms More than Men, Cambridge, 1997, f. 50.

${ }^{8}$ Berryman, C. L., \& Eman, V. A., Language and GenderCommunication, Language and Sex, United States, 1983, f.30-35.

${ }^{9}$ Drass, K. A., The Effect of Gender Identity on Conversation Author, United States, 1986, f. 234.
} 


\section{Case Study}

Students were presented with a number of statements about social and language stereotypes. For each statement they had to choose a number from 1 to 5 (1-totally disagree, 5-totally agree).

(1) Male and female communication might fall into misunderstanding, because of cultural differences each gender represent. But: males and females do not represent different cultural approaches to communication. 1

2

Aspak dakort pak dakort

Students' opinions:

Pro: "we live in the same country, society, this should make us all think that there should not be any essential difference between males and females. Livestyles and way of thinking must not be ruled by society, rather by the individual itself."

Against: males and females have never had and will never have similiar positions. Both represent beings who think and act differently. Social division on gender base proves that they belong to two different worlds, parallel to each - other. As a result, they belong to two different cultures."

Students' asnwres calculated in \% are:

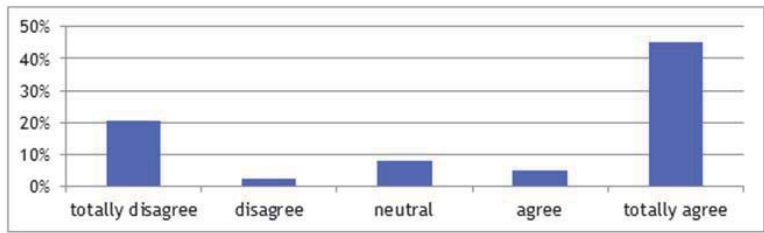

Figure 3.1. Gender misunderstanding

As it is seen in the graphic, almost half of the students who filled in the questionnarie, $42 \%$, disagree with the claim. While $45 \%$ of the students totally agree with the statement that both genders do not represent two different cultures.

(2) Put a number from 1 to 5 for the following statements:

Tabel 3.1. Deklaratat në lidhje me përgjithësimet socio-kulturore.

\begin{tabular}{|c|c|c|c|}
\hline & \begin{tabular}{l|l|l|l}
1 & 2 & 3 \\
3
\end{tabular} & 3 & \\
\hline Females do more gossip than males. & & & \\
\hline Males interrupt conversation more than females. & & & \\
\hline Females use in abundance terms of politeness. & & & \\
\hline Males contradict each-other in conversation more often than females contradict each-other & & & \\
\hline Females have the tendency to talk more about the same topic. & & & \\
\hline
\end{tabular}

The answers are as such:

Boys and girls admitted that are the girls those who talk more and use a more convincing style in conversation and an abundant number of polite words. While boys interrupt more each-other in conversations.

Results are given in the chart below:

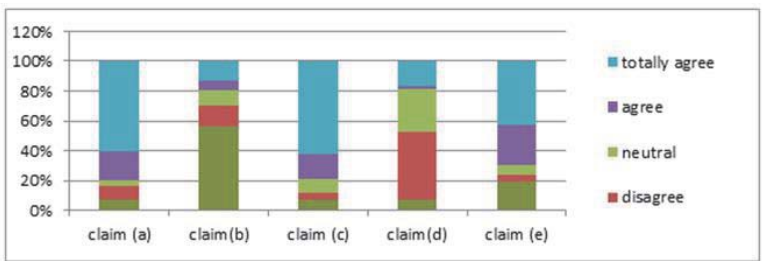

Figure 3. 2. Students' answers about generic statements on gender 
The analysis of discussions, conversations and questionnaire, featured some characteristic of gender discourse: female discourse is more careful in making statements; sometimes hesitating and emotional [6]. If one listens attentively girls talking in the class or outside the auditorium (topic of conversation is about lectures), it can observe that they:

1. Use explanatory phrases and modification, using words like: domethënë (that is), kështu pra (so therefore), ashtu (also), duket sikur (it seems), etc...;

2. Use courtesy expressions, such as: "e ke problem sikur..." (Do you mind if ...),"Do të më bëhej shumë qejfi sikur ..."(I was very happy if ...);

3. Use tag questions: "Po ti, do ikësh në mësim?" (And you, will you attend the lecture?);

4. Emphasize certain words through intonation - kështu që (so), shumë (too), goxha bukur (pretty nice);

5. Excessed the use of adjectives: fantastike (fantastic), i bukur (beautiful), i madh fare (great);

6. Girls use more direct statements while boys express their thoughts in a more indirect way;

7. Use the asking word "Pse?" (Why?). Such as, "Pse nuk e hapni derën?") "Why do not you open the door?" Girls ask more questions than boys;

8. Use highly decorated expression, but also sentences that express disbelief;

9. Excessive use of the verb: mendoj... (think), thashëunë... (I said);

10. Apologize more: (for example, "Më vjen keq, por unë mendoj se..." (I'm sorry, but I think ...);

11. Use modal constructions, such as: mund të (may), do (will), duhet (should), "A duhet të dalim tani?" (Do I have to go now?);

12. Use words that emphasize understanding, for example, "Unë jam aq e kënaqur që erdhët!" (I'm so glad you came!);

13. Feminine discourse also uses more pronouns, verbs and social words; words that describe different emotional and psychological condition. Denial words and terms about house are also features of their discourse.

(3) Mark which feature belongs to males / females or both genders:

Table 3. 2. Përcaktimi i tipareve sociale sipas gjinisë.

\begin{tabular}{|c|c|c|c|c|c|c|c|c|}
\hline & 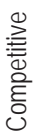 & 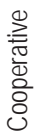 & 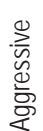 & 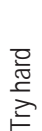 & 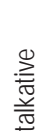 & 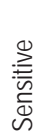 & 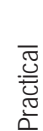 & 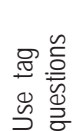 \\
\hline Males & $\uparrow$ & & $\uparrow$ & & & & $\vec{\uparrow}$ & \\
\hline Females & & & & $\uparrow$ & $\uparrow$ & $\uparrow$ & & $\uparrow$ \\
\hline Both genders & $\uparrow$ & $\uparrow$ & & $\uparrow$ & & & & \\
\hline
\end{tabular}

Students' answers brought into light a cultural stereotype which is deeply rooted in language as well: $54 \%$ have the conviction that males are more competitive than females; $46 \%$ think that both genders are equally competitive.

After an accurate interpretation of the questionnaire outcome, we reached the conclusion that boys' linguistic performance are different from those of the girls'.

Thus, boys use a concise, direct language. Their tone of voice expresses strength and power. Most of their speech is short. Girls use a lot of affirmative questions and most of their declarative statements end in a rising intonation, as a question.

\section{Discussion}

Boys consider communication as a tool that serves to exchange information, that is, they speak when they have something to say, when you want to reach a certain goal, focus less on the affective side of speech and do not provide many details about an issue. Girls communicate to establish a relation with others, to discuss a case in which the emotional aspect prevails and they give a detailed recount of the case.

Female discourse features that are stated above are not universal, because they appear in a part of the girls, and a significant part of them reflect security, confidence, and strength in their discourse. Changes in gender speech are less visible in developed societies and more prevalent in economically underdeveloped societies, where women do not play a pivotal role in the society and family.

Regardless the level of culture or education of the student girls, polls and surveys conducted in the aforementioned 
institution have shown that: $78 \%$ of girls displayed assertiveness in their discourse, but most of their affirmative statements ended in a rising intonation, if they were asking a question. This feature shows women attempt to equalize with the boys position, but also shows a lack of confidence in saying their opinions.

After finishing the process of gathering and interpreting linguistic data of both genders, we can conclude that such work it was easy and difficult. Many students considered quite interesting the study of language and gender. Our research gave them a possibility to express their point of views. This attitude helped us to gather easily data for our research.

Meanwhile, we encountered a difficulty, which made us deal with the issue of subjectivity. Questionnaire and observations of students' linguistic exchange highlighted the hypothesis that students would have been influenced by their cultural and social background.

The saying "Men are from March, women are from Venues" is just a metaphor. Males and females differ from their sex, which is the root of every social and cultural difference. This difference is reflected in language as well. We are products of our society.

\section{References}

Johnson, S., \& Meinhof, U. H., Language and masculinity, Oxford, 1999, f. 310.

Bodine, A., Review of: Male/Female Language , Cambridge , 1977 , f. 104-110

Manual për të rinjtë e mësuesit: Adoleshentët dhe çështjet gjinore: perspektiva gjinore. Tiranë, 2005, f. 5, 8.

Bhasin, K., Të kuptosh përkatësinë gjinore, Tiranë, 2006, f. 23.

Gordon, E., Sex, Speech, and Stereotypes: Why Women Use Prestige Speech Forms More than Men, Cambridge, 1997, f. 50.

Berryman, C. L., \& Eman, V. A., Language and GenderCommunication, Language and Sex, United States, 1983, f.30-35

Drass, K. A., The Effect of Gender Identity on Conversation Author, United States, 1986, f. 234. 